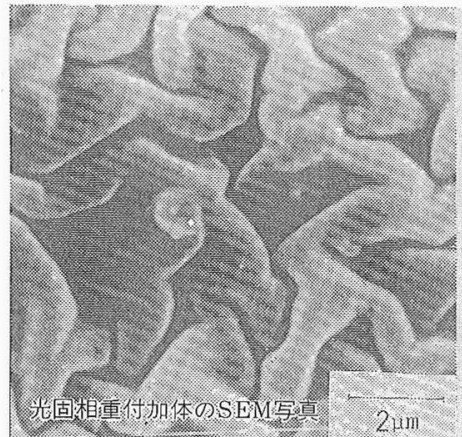

1.はじめに

固相重合で高分子を合成する試みは，これまでに 種々検討されてきた。例えば 2,5-ジスチリルピラジ ンの紫外線や可視光による重合 ${ }^{1)}$, トリオキサンの $\gamma$ 線固相重合 ${ }^{2)}$ やカチオン触媒固相重合 ${ }^{3}$, ジアセチレ ン誘導体の固相重合4) などの例がある．固相重合では モノマーの配列や運動状態が結晶格子によって規制さ れているので, 溶液重合と比較し, 構造の異なるポリ マーが生成したり，生成ポリマーが特異な集合状態を とる場合もある。例えば, トリオキサンでは, 極めて 配向性の良い高分子結晶が得られ, ジアセチレン誘導 体では非線形光学効果を有するポリマー結晶が合成可 能5)である。

筆者らは, 炭素-炭素の二重結合や三重結合とチオ ール基やセレノール基のラジカル重付加反応で, 新し い主鎖の高分子合成法を見いだした6).このような付 加反応は古くから知られていたが7)，この反応を用い て高分子合成を試みた例は少数である ${ }^{8}$. モノマーは 1,4-ベンゼンジチオール (BDT) や 1,4-ジエチニル ベンゼン (DEB) などの比較的単純な化合物である. BDT と DEB は昇華精製して重合に用いるが, 両者 を等モル混合して昇華すると，両モノマー成分を等モ ル含む混合モノマー薄膜が得られた。基板としては顕 微鏡用のカバーガラスを用いた。ガラス板に担持した 混合モノマー薄膜を実験台上に置き, 数分間観察して いると薄膜はしだいに薄黄色に変化し, 有機溶媒不溶 のポリマーになった。この現象が契機となり，一連の ジチオール誘導体およびジアセチル誘導体の合成と溶 液重付加6)および光固相重付加9) の研究が始まった。 これまでに検討した主なモノマーと代表的なポリマー の例を(1)式に示す。

Syntheses of Highly Crystalline Thin Layer Polymers by Solid State Polyadditon - Reversible Phase Transition of Thin Layer Conjugated Polymers by Photon Mode
極めて興味あることに, 光固相重付加で合成したポ リマー薄膜はX線解析によると層構造である ${ }^{10)}$. 特定 波長の光で層構造が増加したり, 減少したりするが, これが可逆的に起こる ${ }^{11}$. 層構造の増減に対応して約 $500 \mathrm{~nm}$ における拡散反射スペクトルも $15 \%$ 程度変化 する．相転移速度や光に対する感度も十分に大きいの で，新しい高分子光記録材料としての可能性がある が，学術的にも幾つもの問題を提起しているのでやや 詳細に述べる。

\section{2. 光固相重合によるポリマー薄膜の合成9,10)}

昇華精製した等モル量の BDT と DEB を Nicolaysen の昇華装置にいれて混合する。通常は 0.5 $\mathrm{mmHg}$ の減圧下で $60^{\circ} \mathrm{C}$ 加熱し, $1: 1$ 組成の混合モ ノマーの薄膜をガラス基板上に蒸着させる、組成はイ オウ分析值から求められた。図 1 はそれぞれのモノマ 一, 混合モノマー薄膜扔よびポリマー薄膜のX線図で ある。ポリマー薄膜は, チオールモノマーと類似した X線図を示すことがわかる. しかも, 小角側の回折線 $7.73 \AA$ の約 $1 / 2 ， 1 / 3 ， 1 / 4$ のところにそれぞれ回折が みられ，層構造を有するポリマー薄膜が生成したと考 えられる、銅アセチリド法で求めたポリマーの分子量 $\bar{M}_{\mathrm{n}}$ は $3,000 \sim 4,000$, 平均重合度 $n$ は $11 \sim 15$ で, 主 鎖中のビニレン基は主としてシス型である。熱分解点

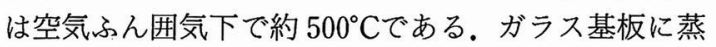
着した $1: 1$ 組成の混合モノマー薄膜が，固相重合す

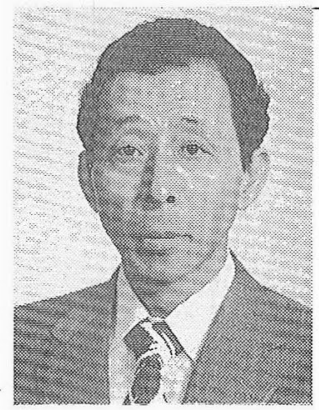

小林英一 東京理科大学 $(278$ 野田市山崎 2641) 教授, 工博 1964年京大大学院工修了. 1964 1965年ベルン大有機化学 研に留学. 1967年京大化研助 手，1976年東理大講師，1982年 教授。専門は高分子合成，触媒 化学. 現在の研究は重合触媒, 有機ガラスの合成, 共役系高分 子薄膜の合成と光物性. 
<smiles>C#Cc1ccc(C#C)cc1</smiles><smiles>C#Cc1ccc(-c2ccc(C#C)cc2)cc1</smiles><smiles>C#Cc1ccc(C#C)s1</smiles><smiles>C#Cc1c2ccccc2c(C#C)c2ccccc12</smiles>

(1)

るためには，モノマーの配列が規則的になっている必 要がある。例えば，混合モノマーは molecular complex を形成していると推定される。事実, 拡散反射 スペクトルを測定すると，混合モノマーには約 400 $\mathrm{nm}$ に新たな大きな吸収が生じていることがわかった (図 2).このような層構造と推定されるポリマー薄膜

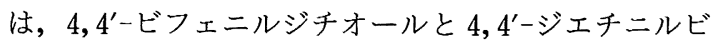
フェニルの混合モノマー薄膜の光固相重合でも得ら れ12)，9,10-アントラセンジチオールと 9,10-ジエチ ニルアントラセンの重付加の場合には, 溶液重合で沈 殿したポリマーが層構造である ${ }^{13)}$. したがって, 交互 連鎖配列の共役系ポリマーの合成とポリマー分子の特

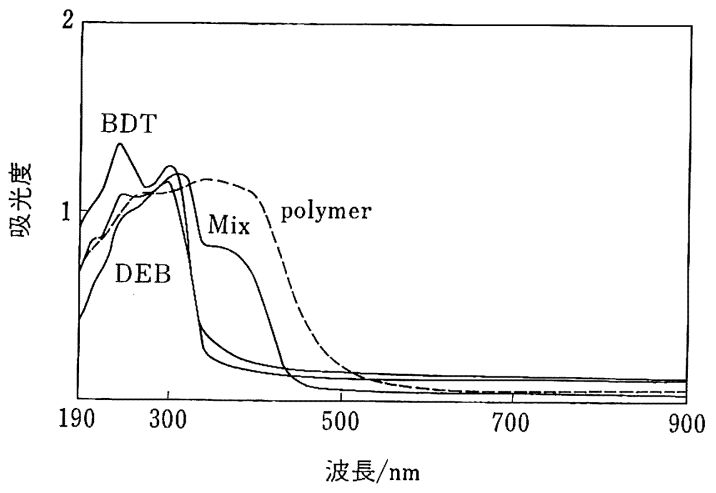

図 2 BDT, DEB， 1: 1 モノマー薄膜および ポリマー薄膜の拡散反射スペクトル
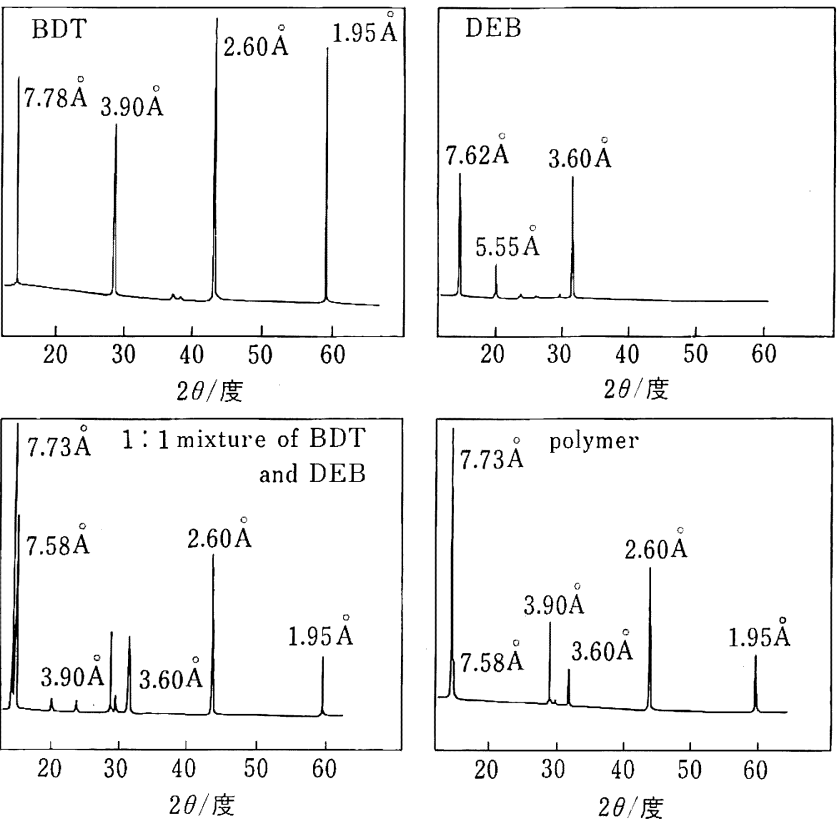

重合温度 $60^{\circ} \mathrm{C}$, 時間 10 分, $300 \mathrm{~W}$ 高圧水銀灯照射 窒素ふん囲気下，ポリマー収率 $93 \%$

図 1 BDT, DEB, 1:1 モノマー薄膜およびポリマー 薄膜の $\mathrm{X}$ 線図

殊な集合状態を作る方法として，筆者らの研究は極め て興味ある事例である。

\section{3. ポリマー薄膜の光相転移 ${ }^{10), 11), 14)}$}

BDT と DEB の光固相重合で合成した結晶性ポリ マー薄膜は $40^{\circ} \mathrm{C}$ 以上でしだいに結晶性が低下する. $75^{\circ} \mathrm{C}$ では 60 分後には完全に非晶となった. DSC によ ると $75,95,130^{\circ} \mathrm{C}$ 発熱ピークが認められる. $75^{\circ} \mathrm{C}$ は層構造の破壊に伴う発熱ピーク, $95^{\circ} \mathrm{C}$ はシスかト ランスへの異性化に伴う発熱ピークと帰属された。し たがって，層構造は非晶構造よりエネルギ一的に不安 定な状態である。

興味あることに, 結晶性高分子薄膜に光を照射する と,ポリマーの層構造に由来するX線の回折強度が増 加したり, 減少したりする。例えば, 545.6, 567.8, $590.1 \mathrm{~nm}$ の光はその回折強度を増加させるが, $539.6,588.1 \mathrm{~nm}$ の光はその回折強度を低下させる (図 3). 照射エネルギーは $50 \sim 60 \mathrm{~mJ} \cdot \mathrm{cm}^{-2} \mathrm{hr}^{-1}(500$ 〜 $600 \mathrm{~nm}$ ) である. 用いた高分子薄膜の厚みは約 10 $\mu \mathrm{m}$ であり, 薄膜による光の干渉効果も無視できない ように思われる。そこで薄膜の厚みを 5〜30 $\mu \mathrm{m}$ に変 化して同様な実験を行ったが, 同じ結果が得られた. したがって, 光相転移現象はこのポリマー薄膜に固有 


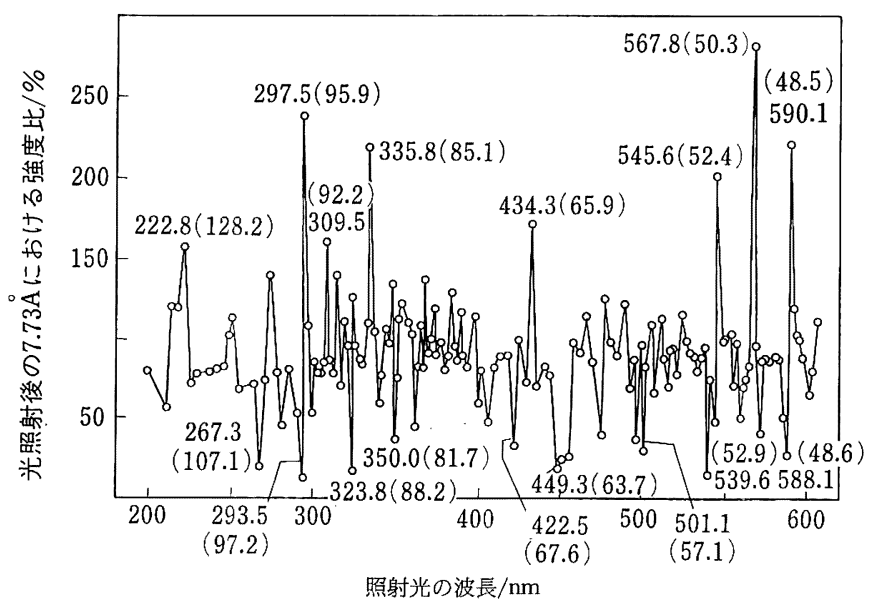

60 分間照射, $18 \sim 22^{\circ} \mathrm{C}$, 空気示ん囲気下 $\left(\mathrm{kcal} \cdot \mathrm{mol}^{-1}\right)$ 図 3 ポリマー薄膜の相転移に及ぼす光の波長の影響

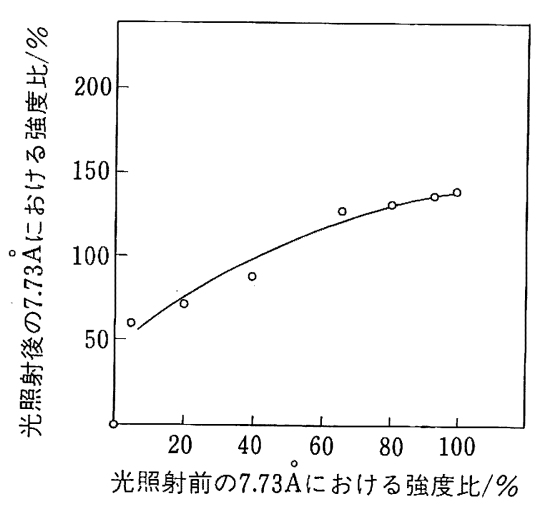

$545.6 \mathrm{~nm}, 60$ 分間照射, $20^{\circ} \mathrm{C}$, 空気子ん囲気下

図 4 光照射によるポリマー薄膜の 層構造の回復
の現象と考えられる.

このポリマー薄膜の層構造は $545.6 \mathrm{~nm}$ と 571.8 $\mathrm{nm}$ の光を交互に照射すると可逆的に増減する。この ような現象は従来ほとんど知られておらず，筆者らに とっても予想外な結果である。

さらに興味あることに，このポリマー薄膜は一種の 記憶機能を有している.ポリマー薄膜は熱処理をする と，最後には層構造が完全に破壊される，このような ポリマー薄膜に, 例えば $545.6 \mathrm{~nm}$ の光を照射して も，層構造はもはや再生されない。しかし，数\%の 層構造が残っているポリマー薄膜に $545.6 \mathrm{~nm}$ の光を 照射すると，層構造が再び増加する(図 4).

Avrami 型のプロットを行うと, 相転移は 3 次元転 移であることがわかった，つまり，光子が高分子薄膜 に入射すると, この光子により相転移が誘発され，こ れが契機となり 3 次元方向に転移が起こると解釈でき る.したがって, 光による相転移の感度が極めて高く なる。

光記録材料として用いる場合には, 熱転移を防止し 記録の保存性を良くする必要性がある。この対策の一 つは PMMA などのポリマー溶液にポリマー薄膜を浸 し，ポリマー薄膜の層間に PMMA を包接し，ポリマ 一薄膜の熱相転移を抑制する試みである. 分子量 1 万 程度の PMMA を包接すると, PMMA の $T_{\mathrm{g}}$ は $105^{\circ} \mathrm{C}$ から $115^{\circ} \mathrm{C}$ 上昇し， $75^{\circ} \mathrm{C}$ あったポリマー薄

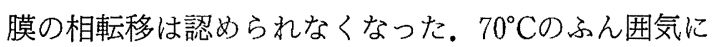
この処理済みのポリマー薄膜を保存すると, $7.73 \AA$ の 回折強度は初期の値の $70 \%$ 程度の一定值に収束し, しかも光による相転移機能は保持している.したがっ て,このような方法で熱転移はかなり抑制できる.
第 2 は, モノマーの骨格構造をフェニレン基から他 の基に変える試みである。このような見地からビフエ ニル誘導体とアントラセン誘導体の重付加体の合成を 行った.これらのポリマーは熱に対する層構造の安定 性はかなり良く, $100^{\circ} \mathrm{C}$ 以上でも層構造を保持したま まである、目下, 光相転移を詳細に検討中であり, 次 の機会に述べてみたい.

\section{4. 主鎖のミクロ構造と相転移 ${ }^{15)}$}

$60^{\circ} \mathrm{C}$ 光固相重合で得られるポリマー薄膜は, シス が平均 $83 \%$ ，トランスが 17\% であり，シスの含有率 はモノマーの昇華温度 $\left(45 \sim 80^{\circ} \mathrm{C}\right)$ や，基板の冷却温 度 $\left(6.5 \sim 15.1^{\circ} \mathrm{C}\right)$ には依存しない. しかし, 重合温度 が 0 から $60^{\circ} \mathrm{C}$ 高くなると，シスは $90 \%$ からしだい に低下する。一方, 溶液重合では重合温度 $\left(0 \sim 60^{\circ} \mathrm{C}\right)$ が変化しても，シスは約 $93 \%$ と一定值を示した。溶 液重合ポリマーは高シスでありながら，X線的には非 晶質であり，層構造は全く認められない，したがっ て, シス構造と層構造が直接関連しているわけではな い. また，ポリマー薄膜を $60^{\circ} \mathrm{Cで}$ 熱処理すると層構 造はしだいに破壊されるが，シスの值は $83 \%$ と一定 値を保っている. $95^{\circ} \mathrm{C}$ 程度で熱処理すると，層構造は 急激に減少し，シスの值も低下する，なお，このポリ マーは有機溶媒に不溶であるので，ミクロ構造はポリ マーの IR を $\mathrm{KBr}$ 法で測定して求めた，定量に用い たシスの特性吸収帯は $1,350 \mathrm{~cm}^{-1}\left(\varepsilon=124.5 l \mathrm{~mol}^{-1}\right.$ $\left.\mathrm{cm}^{-1}\right)$, トランスの特性吸収帯は $940 \mathrm{~cm}^{-1}(\varepsilon=333.6$ $\left.l \mathrm{~mol}^{-1} \mathrm{~cm}^{-1}\right)$ であり， $\varepsilon$ の值は低分子モデル化合物を 用いて決定した。

可逆的光相転移機構を明らかにするため, 相転移に 
表 1 ポリマー薄膜のミクロ構造(a) と $\mathrm{X}$ 線の回折強度に 及ぼす光の波長の影響

\begin{tabular}{|c|c|c|c|c|c|c|c|c|}
\hline & \multicolumn{8}{|c|}{ 照射時間 (min) } \\
\hline & \multicolumn{4}{|c|}{$539.6 \mathrm{~nm}$} & \multicolumn{4}{|c|}{$545.6 \mathrm{~nm}$} \\
\hline & 0 & 30 & 65 & 120 & 0 & 20 & 40 & 60 \\
\hline$\underset{\%}{c i s / t^{2} a n s^{a)}}$ & $\begin{array}{l}85 \\
/ 15\end{array}$ & $\begin{array}{l}83 \\
/ 17\end{array}$ & $\begin{array}{l}78 \\
/ 22\end{array}$ & $\begin{array}{l}70 \\
/ 30\end{array}$ & $\begin{array}{l}72 \\
1 / 28\end{array}$ & $\begin{array}{l}75 \\
/ 25\end{array}$ & $\begin{array}{l}80 \\
/ 20\end{array}$ & $\begin{array}{l}88 \\
/ 12\end{array}$ \\
\hline $\begin{array}{l}7.73 \AA \\
\text { に扔ける } \\
\text { 強度比 \% }\end{array}$ & 100 & 65 & 35 & 20 & 100 & 110 & 125 & 147 \\
\hline
\end{tabular}

a) IR 法, cis $1,350 \mathrm{~cm}^{-1}$, trans $950 \mathrm{~cm}^{-1}$

パラメータを求めるのが先決である。

\section{6. おわりに}

チオール基とエチニル基の重付加で新 しい分子構造の高分子を合成するルート を開拓してきたが，固相重付加では層構 造のポリマー薄膜が合成できることがわ かった。このポリマー薄膜は，光により 高感度で可逆的相転移を起こし，テルル 系以外の新しい光記録用薄膜として用い ることも可能と思われる．相転移の機構 は目下のところでは推定の域にすぎない

伴うポリマーのミクロ構造の変化を調べてみた，その 一例を表 1 に示す。つまり，層構造を減少させる $539.6 \mathrm{~nm}$ の光を照射すると, ポリマーのシス含有率 は減少し, 層構造を増加させる $545.6 \mathrm{~nm}$ の光を照射 すると，ポリマーのシス含有率は増加した。このこと より, 光相転移はシス・トランスの異性化に伴って 3 次元的に起こるといえる. しかし，なぜシス・トラン スの異性化が光相転移の誘引となるのか, あるいは相 転移に有効な光の波長がとびとびではあるがかなり広 い波長領域にわたって存在する理由については，現在 検討中である. 目下，有効波長の精密測定と分子間の $\pi$ 電子の摂動についての対応関係を調べている.

\section{5. なぜシス付加体が生成するのか ${ }^{16)}$}

BDT と DBE の重付加体はビニレン基がシスにな っているが，重合反応の進行に伴ってシスの含有率が やや減少する。一方，ポリマーを $95^{\circ} \mathrm{C}$ 以上で熱処理 すると, シスの含有率は急激に低下し，50\%以下と なった。これらのことはシス付加体の付加の遷移状態 の $\Delta H^{\mp}$ がトランス付加体のそれよりも低いことを示 唆している。 また，トランス付加体の $\Delta H$ はシス付 加体の $\Delta H$ より低いと予想される。この点を検討す るために MINDO $/ 3$ 法でそれぞれの $\Delta H^{*}$ と $\Delta H$ を 求めた。計算の結果, ポリマーのシスのミクロ構造は kinetic control であるが，重合中にシス 異性化が多少併発しており, thermodynamical control ではトランス付加体となることがわかった。 kinetic control でシス付加体が生成するのはチオフェ ン誘導体などもあるが，同じ kinetic control でもト ランス付加体が生成するのは，2,6-ピリジン誘導体の 場合である。

ベンゼンセレノールもフェニルアセチレンに付加 し, 付加体は $100 \%$ シス構造である. $60^{\circ} \mathrm{C}$ 程度の条件 では, シスからトランスへの異性化は認められない。 この系の量子化学的計算も念頭にあるが，信頼できる
が, この機構を明らかにすることは, 学術的には大き な意義があると思われる。したがって，新しい分子の 設計と合成は今後とも私らに新しい材料と学術的課題 を提供してくれるものと信じ，この稿を終わりにした い.

それにしても，筆者の浅学から大きな愦りをおかし ている可能性もあるが, 諸兄のおしかりとご指導のほ ぞを切にお願いいたします。

\section{文献}

1) M. Hasegawa, Y. Suzuki : J. Polymer Sci., B5, 813 (1967)

2) S. Okamura, K. Hayashi, Y. Kitanishi, M. Nishi : Makromol. Chem., 47, 237 (1961)

3) S. Okamura, E. Kobayashi, T. Higashimura: $J$. Polymer Sci., C No.4, 827 (1964)

4) G. Wegner: Pure and Appl. Chem., 49, 443 (1977)

5) H. Matsuda, H. Nakanishi, N. Minami, M. Kato : Mol. Crist. Liq. Crist., 160, 241 (1988)

6) E. Kobayashi, T. Ohashi, J. Furukawa : Makromol. Chem., 187, 2525 (1986)

7) J. March: Advanced Organic Chemistry, J. Wiley and Sons, N.Y. 1985, p.678

8) J.R. Majer, J. Morton: J. Chem. Soc., B1969, 301

9) E. Kobayashi, T. Ohashi, J. Furukawa: J. Polymer Sci. A. Polymer Chem., 25, 2077 (1987)

10）小林英一, 大橋豊史, 古川淳二, 日本化緎研報告, 43,95 (1986)

11) ibid., 44, 96 (1987)

12）小林英一，金田俊和，大橋豊史，古川淳二：Polymer Preprints, 37 (1), 264 (1988)

13）小林英一, 姜 健, 太田浩智, 青島貞人, 古川淳二 : Polymer Preprints, 38 (2), 329 (1989)

14) E. Kobayashi, T. Ohashi, J. Furukawa: Polymer J., to be published

15) E. Kobayashi, T. Ohashi, J. Furukawa : Polymer J., 21, 111 (1989)

16）小林英一, 石塚康弘, 高着泰則, 古川淳二 : 高分子論文 集, 46, 303 (1989) 